\title{
ANALISIS FAKTOR-FAKTOR YANG MEMPENGARUHI PRESTASI BELAJAR AKUNTANSI
}

\author{
Immaculata Herawati \\ Yuli Widiastuti \\ Universitas Negeri Malang \\ yuli_widiastuti.akuntansi@um.ac.id
}

\begin{abstract}
The purpose of this research is for determining the factors that influence student achievement in accounting class XI IPS SMA Negeri 1 Malang and the most dominant factor influencing accounting student achievement. The research did in SMA Negeri 1 Malang and research subjects are students of class XI-IPS SMA Negeri 1 Malang academic year 2012/2013. Kind of this research are descriptive and instruments that used in the form are questionnaires and documentation. While the technique of data analysis used Pearson Product Moment for validity, Alpha Cronbanch to test reliability, and factor analysis using SPSS 16 for windows to find out what factors are affecting the achievement of accounting subjects. From the data analysis result is known that the factors affecting accounting students' learning achievement are motivation, social environment consisting of the relations among members of the family and student relationships with students, psychology consisting of $\mathrm{EQ}$, study habits, attention, individual modernity, as well as the attitude and readiness IQ factors.
\end{abstract}

Keywords: Accounting, student's achievement

\begin{abstract}
Abstrak: Penelitian ini bertujuan untuk mengetahui faktor-faktor yang mempengaruhi prestasi belajar akuntansi siswa kelas XI IPS SMA Negeri 1 Malang dan faktor yang paling dominan dalam mempengaruhi prestasi belajar akuntansi siswa. Penelitian ini dilakukan di SMA Negeri 1 Malang, dan subjek penelitiannya adalah siswa kelas XI IPS SMA Negeri 1 Malang tahun ajaran 2012/2013. Jenis penelitian ini adalah deskriptif dan instrumen yang digunakan berupa kuisioner dan dokumentansi sedangkan teknik analisis datanya menggunakan Pearson Product Moment untuk uji validitas, Alpha Cronbanch untuk uji reliabilitas, dan analisis faktor menggunakan SPSS 16 for window untuk mengetahui faktor-faktor yang mempengaruhi prestasi belajar akuntansi. Dari hasil analisis data diketahui bahwa faktor-faktor yang mempengaruhi prestasi belajar akuntansi siswa yaitu motivasi, lingkungan sosial yang terdiri dari relasi antaranggota keluarga dan relasi siswa dengan siswa, psikologi yang terdiri dari EQ, kebiasaan belajar, perhatian, modernitas individu, sikap dan kesiapan serta faktor IQ.
\end{abstract}

Kata Kunci : Akuntansi, Prestasi Belajar.

Kemajuan pesat dalam dunia ilmu pengetahuan dan teknologi harus diiringi dengan kemajuan sumber daya manusia yang berkualitas. Salah satu cara peningkatan sumber daya manusia melalui peningkatan mutu pendidikan, karena dengan mutu pendidikan yang berkualitas akan menghasilkan sumber daya 
manusia yang berkualitas pula. Sumber daya yang berkualitas akan menghasilkan ilmu pengetahuan dan teknologi yang berkembang pesat sehingga dapat dimanfaatkan secara maksimal untuk kemajuan bangsa.

Cara untuk mengetahui suatu pendidikan berkualitas atau tidak dengan melihat prestasi belajar siswa. Prestasi belajar adalah kesempurnaan yang dicapai seseorang dalam berfikir, merasa dan berbuat (Nasution, 2009:17). Prestasi belajar dikatakan sempurna apabila memenuhi tiga aspek yakni kognitif, afektif dan psikomotor, sebaliknya dikatakan prestasi kurang memuaskan jika seseorang belum mampu memenuhi target dalam ketiga kriteria tersebut.

Prestasi belajar siswa dipengaruhi oleh berbagai faktor, tetapi dapat digolongkan menjadi dua golongan saja. Faktor tersebut yaitu faktor intern dan faktor ekstern. Faktor intern adalah faktor yang ada dalam diri individu yang sedang belajar, sedangkan faktor ekstern adalah faktor yang ada di luar individu. Menurut Slameto (2010: 54), faktor intern meliputi kesehatan jasmani, cacat tubuh, intlegensi, perhatian, minat, bakat, motivasi belajar, kesiapan, sikap siswa dan kelelahan.

Faktor intern lain yang mempengaruhi prestasi belajar siswa yaitu faktor EQ (Emotional Quotient). Goleman (2004:44) mengungkapkan bahwa manusia memiliki suatu jenis potensi dasar yang lain, yaitu kecerdasan emosional (EQ : Emotional Quotient), menurut pendapatnya bahwa IQ akan dapat bekerja secara efektif apabila seseorang mampu memfungsikan EQ-nya. IQ hanyalah merupakan satu unsur pendukung keberhasilan seseorang, keberhasilan itu akan tercapai tergantung kepada kemampuan seseorang menggabungkan IQ dan EQ.

Kecerdasan emosi merupakan bagian dari aspek kejiwaan seseorang yang paling mendalam, dan merupakan suatu kekuatan, karena dengan adanya emosi itu manusia dapat menunjukkan keberadaannya dalam masalah manusiawi (Aunurrahman, 2009:95). Pemahaman guru terhadap kecerdasan emosional serta pengetahuan tentang cara-cara penerapannya kepada siswa pada saat ini merupakan bagian penting dalam rangka membantu mewujudkan perkembangan potensi-potensi siswa secara optimal yang berpengaruh positif terhadap prestasi belajar siswa. 
Djaali (2009) berpendapat kebiasaan belajar termasuk faktor intern yang mempengaruhi prestasi belajar siswa. Kebiasaan belajar adalah cara atau teknik yang menetap pada diri siswa pada waktu menerima pelajaran, membaca buku, mengerjakan tugas, dan pengaturan waktu untuk menyelesaikan kegiatan. Kebiasaan belajar cenderung menguasai perilaku siswa pada setiap kali mereka melakukan kegiatan belajar, karena itu kebiasaan yang baik perlu dimiliki oleh setiap siswa. Kebiasaan baik yang dilakukan secara terus menerus akan membentuk suatu kebiasaan yang bersifat relatif tetap. Siswa yang memupuk kebiasaan belajar dengan baik akan memperoleh kemudahan dalam belajar dan meraih prestasi belajar yang bagus.

Modernitas individu termasuk faktor intern yang mempengaruhi prestasi belajar siswa. Penelitian yang dilakukan oleh Khaque (2009) menyatakan bahwa modernitas individu memiliki pengaruh terhadap prestasi belajar siswa. Siswa yang memiliki modernitas individu tinggi maka rata-rata mereka juga memiliki prestasi belajar yang tinggi juga dan begitu pula sebaliknya siswa yang memiliki modernitas individu rendah maka rata-rata mereka memiliki prestasi yang rendah pula.

Modernitas individu siswa dimaksudkan bahwa siswa diharapkan tidak hanya memperoleh pengetahuan dari sekolah dan apa yang disampaikan oleh guru saja tetapi siswa juga dapat memperoleh dan mencari informasi sendiri dari luar yaitu melalui media cetak maupun elektronik. Disamping itu siswa juga dapat belajar dalam berbagai kesempatan dan kegiatan di luar sekolah, sehingga siswa mampu untuk berfikir kritis dan kreatif ke masa depan dan siap menerima hal-hal baru. Melalui tambahan informasi yang diperoleh dari luar tersebut diharapkan siswa dapat lebih termotivasi untuk mengembangkan potensi yang ada dalam dirinya dan meningkatkan prestasi belajarnya.

Faktor ekstern menurut Slameto (2010:54) meliputi cara orang tua mendidik, relasi antaranggota keluarga, suasana rumah, metode mengajar, relasi guru dengan siswa, relasi siswa dengan siswa, keadaan gedung, teman bergaul dan waktu sekolah. Ketaatan siswa dalam melaksanakan peraturan sekolah termasuk faktor eksternal yang mempengaruhi prestasi belajar siswa. Setiap sekolah memiliki peraturan yang harus ditaati oleh siswa, dengan menaati peraturan diharapkan 
siswa dapat menjadi orang yang berprestasi. Hurlock (2000:78) menyampaikan "pada waktu anak-anak masuk sekolah, mereka belajar bahwa tingkah laku mereka dikendalikan oleh peraturan sekolah". Dalam hal ini siswa menyadari bahwa sekolah memiliki peraturan yang harus ditaati selama berada di lingkungan tersebut. Penerapan peraturan sekolah yang baik mengharuskan guru agar dapat bertindak sebagai pengendali peraturan dan dapat memberikan pengarahan atau memberikan hukuman jika siswa ada yang melanggar peraturan sekolah dengan tujuan untuk memperbaiki sikap siswa. Penerapan atau pelaksanaan peraturan yang tegas diharapkan dapat meningkatkan disiplin siswa sehingga segala aktivitas belajar dapat terarah dan terorganisir dengan baik. Aktivitas belajar yang terorganisir dengan baik menghasilkan prestasi belajar siswa yang meningkat.

Salah satu komponen penting dalam proses belajar mengajar adalah adanya sumber belajar. Sumber belajar merupakan salah satu faktor eksternal yang mempengaruhi prestasi belajar siswa. Dimyanti (2002:249) berpendapat bahwa lengkapnya sarana dan prasarana pembelajaran merupakan kondisi pembelajaran yang baik. Penggunaan sumber belajar yang optimal akan membantu siswa dalam memahami materi yang disampaikan guru. Semakin banyak sumber belajar yang dapat diperoleh siswa, akan membantu siswa dalam memahami materi yang disampaikan sehingga prestasinya dapat meningkat.

Berdasarkan uraian di atas, maka perlu dilakukan analisis terhadap faktorfaktor yang mempengaruhi prestasi belajar siswa. Analisis dilakukan untuk mereduksi faktor-faktor yang mempengaruhi prestasi belajar siswa menjadi lebih kecil dari sejumlah faktor yang dianalisis. Hasil dari reduksi akan memperlihatkan faktor-faktor apa saja yang berpengaruh besar terhadap prestasi belajar siswa. Hal inilah yang memotivasi dilakukannya penelitian ini. Penelitian ini dilakukan di SMA Negeri I Malang karena SMA ini merupakan salah satu SMA favorit di Kota Malang. Hal ini terbukti dengan tingkat kelulusan SMA Negeri 1 Malang yang selalu lulus 100\%, juga beberapa siswanya yang nilai UAN (Ujian Akhir Nasional) termasuk tiga besar se-kabupaten Malang. Melihat prestasi yang diraih SMA Negeri 1 Malang, tidak dapat dipungkiri bahwa para siswa SMA Negeri 1 Malang merupakan siswa yang berprestasi sehingga layak untuk dilakukan penelitian tentang faktor-faktor yang mempengaruhi prestasi belajar siswa. 


\section{METODE}

Penelitian ini termasuk penelitian deskriptif. Penelitian ini menggunakan analisis faktor eksploratori yaitu suatu teknik untuk mereduksi data dari variabel awal menjadi variabel baru yang jumlahnya lebih kecil dari pada variabel awal. Penelitian ini dilakukan pada siswa kelas XI IPS-1 yang berjumlah 21 siswa dan siswa kelas XI IPS-2 SMA Negeri 1 Malang yang berjumlah 20 siswa. Penelitian ini tidak mengambil sampel sehingga termasuk penelitian populasi.

Tehnik pengumpulan data menggunakan angket telah digunakan dalam penelitian ini. Teknik ini digunakan untuk mengumpulkan data mengenai kesehatan jasmani, cacat tubuh, EQ (Emotional Quotient), perhatian, minat, bakat, motivasi belajar, kesiapan, ketaatan siswa dalam melaksanakan peraturan sekolah, sikap siswa, kebiasaan belajar, kelelahan, modernitas individu, cara orang tua mendidik, relasi antaranggota keluarga, suasana rumah, metode mengajar, relasi guru dengan siswa, relasi siswa dengan siswa, keadaan gedung, teman bergaul, waktu sekolah dan sumber belajar Teknik lain yang digunakan dalam penelitian ini adalah teknik dokumentasi. Teknik ini digunakan untuk mengumpulkan data mengenai IQ (Intelligence Quotient) dan prestasi belajar siswa.

Uji hipotesis yang relevan dengan analisis faktor adalah sebagai berikut (Supranto, 2004:118):

1) Correlation Matrix (Uji Idependensi = Kebebasan)

Untuk perhitungan analisis faktor dilakukan dengan teknik analisis Bartlett's test of sphericity. Analisis ini merupakan uji hipotesis statistik yang digunakan untuk mengetahui kebebasan antar variabel. Apabila terdapat koefisien korelasi $\left(\mathrm{r}_{\mathrm{xy}}\right)$ lebih besar dari 0,80 maka variabel tersebut gugur.

2) Kaiser Meyer Olkin (KMO)

KMO mengukur kelayakan sampling. Nilai tinggi antara 0,5 - 1,0 berarti analisis faktor tepat, kalau kurang dari 0,5 analisis faktor dikatakan tidak tepat.

\section{3) Communality}

Koefisien communality cukup efektif apabila bernilai $>50 \%$.

4) Eigenvalue

Faktor yang mempunyai eigenvalue $>1$ akan dimasukkan ke dalam model. 


\section{5) Factor Loading dan Rotasi}

Suatu variabel akan dapat dimasukkan sebagai suatu faktor apabila mempunyai nilai factor loading $>0,50$.

Pada analisis faktor, rumus yang digunakan sebagai berikut:

$\mathrm{X}_{\mathrm{i}}=\mathrm{B}_{\mathrm{i} 1} \mathrm{~F}_{1}+\mathrm{B}_{\mathrm{i} 2} \mathrm{~F}_{2}$ $\mathrm{B}_{\mathrm{im}} \mathrm{F}_{\mathrm{m}}+\mathrm{V}_{\mathrm{i}} \mu_{\mathrm{i}}$

Keterangan:

$\mathrm{X}_{\mathrm{i}}=$ Variabel ke-i yang dibakukan

$\mathrm{B}_{\mathrm{im}}=$ Koefisien regresi parsial yang dibakukan untuk variabel i pada common factor ke-m

$\mathrm{F}_{\mathrm{m}}=$ Common faktor $\mathrm{ke}-\mathrm{m}$

$\mathrm{V}_{\mathrm{i}}=$ Koefisien regresi yang dibakukan untuk variabel i pada faktor unik ke-i

$\mu_{\mathrm{i}}=$ Faktor unik variabel ke-i

(Supranto, 2004:116)

Tabel 1: Hasil Uji Validitas Instrumen

\begin{tabular}{|l|l|l|l|l|}
\hline \multicolumn{1}{|c|}{ Variabel } & $\begin{array}{c}\text { Jumlah } \\
\text { Butir } \\
\text { Awal }\end{array}$ & $\begin{array}{c}\text { Jumlah } \\
\text { Butir } \\
\text { Gugur }\end{array}$ & $\begin{array}{c}\text { Nomor Butir } \\
\text { Gugur }\end{array}$ & $\begin{array}{c}\text { Jumlah } \\
\text { Butir } \\
\text { Valid }\end{array}$ \\
\hline Kesehatan jasmani & 6 & 0 & 0 & 6 \\
\hline Cacat tubuh (Emotional & 6 & 11 & 11 & 5 \\
\hline $\begin{array}{l}\text { EQ } \\
\text { Quotient) }\end{array}$ & 3 & $13,17,20$ & 8 \\
\hline Perhatian & 2 & 0 & 0 & 2 \\
\hline Minat & 4 & 1 & 29 & 3 \\
\hline Bakat & 3 & 0 & 0 & 3 \\
\hline Motivasi belajar & 5 & 0 & 0 & 5 \\
\hline Kesiapan dalam & 2 & 0 & 0 & 2 \\
\hline $\begin{array}{l}\text { Ketaatan siswa } \\
\text { menaati } \\
\text { sekolah }\end{array}$ & 4 & 0 & 0 & 4 \\
\hline Sikap siswa & 2 & 0 & & 2 \\
\hline Kebiasaan belajar & 3 & 0 & 0 & 3 \\
\hline Kelelahan & 4 & 0 & 0 & 2 \\
\hline Modernitas individu & 24 & 12 & $53,56,58,59$, & 12 \\
\hline $\begin{array}{l}\text { Relasi antaranggota } \\
\text { keluarga }\end{array}$ & 2 & & $61,63,65,67$, & \\
\hline Suasana rumah & 2 & 0 & $70,71,74,75$ & \\
\hline & & 0 & 0 & 2 \\
\hline Cara orang tua mendidik & 2 & 0 & 0 & 2 \\
\hline
\end{tabular}




\begin{tabular}{|l|l|l|l|l|}
\hline Metode mengajar & 4 & 2 & 84,86 & 2 \\
\hline $\begin{array}{l}\text { Relasi guru dengan } \\
\text { siswa }\end{array}$ & 2 & 0 & 0 & 2 \\
\hline $\begin{array}{l}\text { Relasi siswa dengan } \\
\text { siswa }\end{array}$ & 2 & 0 & 0 & 2 \\
\hline Keadaan gedung & 2 & 0 & 0 & 2 \\
\hline Teman bergaul & 2 & 0 & 0 & 2 \\
\hline Waktu sekolah & 2 & 0 & 0 & 2 \\
\hline Sumber belajar & 4 & 0 & 0 & 4 \\
\hline
\end{tabular}

Tabel 2: Hasil Uji Reliabilitas Instrumen

\begin{tabular}{|l|l|l|l|}
\hline Variabel & $\begin{array}{l}\text { Alpha } \\
\text { Cronbach }\end{array}$ & $\alpha$ & Keterangan \\
\hline Kesehatan jasmani & .887 & 0,6 & Reliabel \\
\hline Cacat tubuh & .686 & 0,6 & Reliabel \\
\hline EQ (Emotional quotient) & .728 & 0,6 & Reliabel \\
\hline Perhatian & .847 & 0,6 & Reliabel \\
\hline Minat & .660 & 0,6 & Reliabel \\
\hline Bakat & .939 & 0,6 & Reliabel \\
\hline Motivasi belajar & .833 & 0,6 & Reliabel \\
\hline Kesiapan siswa dalam melaksanakan & .943 & 0,6 & Reliabel \\
\hline $\begin{array}{l}\text { Ketaatan } \\
\text { peraturan sekolah }\end{array}$ & .789 & 0,6 & Reliabel \\
\hline Sikap siswa & .827 & 0,6 & Reliabel \\
\hline Kebiasaan belajar & .885 & 0,6 & Reliabel \\
\hline Kelelahan & .886 & 0,6 & Reliabel \\
\hline Modernitas individu & .703 & 0,6 & Reliabel \\
\hline Cara orang tua mendidik & .897 & 0,6 & Reliabel \\
\hline Relasi antaranggota keluarga & .709 & 0,6 & Reliabel \\
\hline Suasana rumah & .838 & 0,6 & Reliabel \\
\hline Metode mengajar & .624 & 0,6 & Reliabel \\
\hline Relasi guru dengan siswa & .956 & 0,6 & Reliabel \\
\hline Relasi siswa dengan siswa & .816 & 0,6 & Reliabel \\
\hline Keadaan gedung & .870 & 0,6 & Reliabel \\
\hline Teman bergaul & .681 & 0,6 & Reliabel \\
\hline Waktu sekolah & .873 & 0,6 & Reliabel \\
\hline Sumber belajar & .729 & 0,6 & Reliabel \\
\hline
\end{tabular}

\section{HASIL DAN PEMBAHASAN}

Berdasarkan hasil analisis faktor yang telah dijelaskan, dapat diketahui dari dua puluh empat variabel yang dianggap mempengaruhi prestasi belajar akuntansi, yang diterima sebagai faktor-faktor yang mempengaruhi prestasi 
belajar akuntansi berjumlah sebelas variabel yaitu IQ, EQ, perhatian, motivasi belajar, kesiapan, sikap siswa, kebiasaan belajar, modernitas individu, relasi antaranggota keluarga, metode mengajar dan relasi siswa dengan siswa. Variabelvariabel tersebut kemudian terotasi ke dalam empat faktor dan dianulir satu variabel lagi yaitu metode mengajar karena nilai variabel tersebut kurang dari 0,5.

Motivasi merupakan faktor utama yang menentukan prestasi belajar akuntansi siswa kelas XI-IPS SMA Negeri 1 Malang. Hal ini sesuai dengan pendapat Djamarah (2011:155) bahwa motivasi mempunyai peranan yang strategis dalam aktivitas belajar seseorang, tidak ada seorangpun yang belajar tanpa motivasi. Hasil skor angket siswa menunjukkan 51\% siswa memiliki motivasi yang berada pada taraf sangat baik, 39\% berada pada taraf baik, dan $10 \%$ pada taraf kurang, sedangkan siswa yang tidak memiliki motivasi belajar berada pada taraf $0 \%$ atau tidak ada sama sekali. Hasil analisis tersebut menunjukan bahwa sebagian besar siswa kelas XI-IPS SMA Negeri 1 Malang memiliki motivasi yang tinggi dalam belajar akuntansi. Motivasi terbukti benarbenar memberikan pengaruh positif dan peranan terhadap prestasi belajar siswa.

Lingkungan sosial merupakan faktor kedua yang menentukan prestasi belajar akuntansi siswa kelas XI-IPS SMA Negeri 1 Malang. Lingkungan sosial disini berupa relasi antaranggota keluarga dan relasi siswa dengan siswa lain. Keluarga merupakan tempat siswa diasuh dan dibesarkan, relasi yang baik antaranggota keluarga akan mempengaruhi pertumbuhan dan perkembangan siswa. Siswa yang memiliki relasi yang baik dengan keluarga akan lebih terbuka terhadap masalah-masalah yang dihadapinya terutama masalah belajar. Relasi antaranggota keluarga yang harmonis juga akan membentuk kepribadian siswa, karena siswa bisa belajar untuk lebih terbuka dan menghargai dalam menerima pendapat orang lain dan peduli terhadap lingkungan sekitarnya. Hasil skor angket menunjukkan siswa kelas XI-IPS SMA Negeri 1 Malang memiliki relasi antaranggota keluarga yang sangat baik sebesar $42 \%$, relasi antaranggota keluarga cukup baik sebesar 56\% dan relasi siswa dengan anggota keluarganya kurang baik sebesar $2 \%$. Tidak ada siswa yang memiliki relasi yang buruk dengan anggota keluarganya. Hal ini dapat disimpulkan bahwa sebagian besar siswa memiliki 
relasi yang baik dengan anggota keluarganya sehingga mempengaruhi prestasi belajar akuntansi.

Relasi antaranggota keluarga juga berkaitan dengan relasi siswa dengan siswa lain. Siswa yang memiliki hubungan baik dengan keluarganya akan membantu siswa lebih mudah untuk bersosialisasi dengan teman-temannya (Juwono, 2002:45). Siswa dalam berelasi atau berhubungan dengan keluarganya secara tidak sadar akan belajar bersosialisasi dengan baik yang kemudian diterapkan siswa ketika berhubungan dengan teman-temannya. Sosialisasi yang baik antara siswa dengan teman-temannya akan membantu siswa dalam belajar.

Psikologi merupakan faktor ketiga yang mempengaruhi prestasi belajar akuntansi siswa kelas XI-IPS SMA Negeri 1 Malang. Faktor psikologi merupakan faktor yang berasal dari diri atau pikiran siswa. Faktor psikologi di sini terdiri dari EQ, kebiasaan belajar, perhatian, modernitas individu, sikap dan kesiapan.

EQ (Emotional Quotient) mempunyai peranan penting dalam meraih prestasi belajar akuntansi, dikarenakan dalam meraih prestasi belajar akuntansi diperlukan kecerdasan emosional yang dapat mengatur serta mengenali emosi yang ada dalam diri pribadi maupun orang lain sehingga dapat menginterprestasikan tindakannya secara tepat dalam meraih prestasi. Hasil penelitian yang dilakukan Goleman (2004:89) menyatakan bahwa kecerdasan emosional mempunyai pengaruh yang cukup besar terhadap prestasi siswa. Setelah anak-anak yang bermasalah dan cenderung agresif diberikan pengajaran dan penelitian tentang kecerdasan emosi mereka menjadi anak yang tenang dan mengalami peningkatan prestasi di sekolah. Hasil skor angket siswa tentang EQ menunjukkan siswa kelas XI-IPS SMA Negeri 1 Malang memiliki EQ sangat baik sebesar $17 \%$, yang memiliki EQ pada taraf baik sebesar $61 \%$, dan $22 \%$ sisanya berada pada taraf kurang baik. Tidak ada siswa yang memiliki EQ yang rendah.

Kebiasaan belajar seseorang sangat menentukan keberhasilan seseorang dalam belajar, karena kebiasaan belajar yang buruk akan membuat orang tersebut malas belajar sehingga hasil belajar yang diperoleh tidak maksimal. Slameto (2010:82) mengatakan bahwa, "kebiasaan belajar juga mempengaruhi belajar itu sendiri”. Untuk mencapai prestasi yang diharapkan maka dalam kegiatan belajarnya siswa hendaknya mempunyai sikap dan cara belajar yang baik. Siswa 
yang memiliki kebiasaan belajar yang baik akan dapat memperoleh hasil belajar yang maksimal.

Kebiasaan belajar bukan merupakan bakat alamiah yang dimiliki oleh seorang siswa sejak lahir tetapi perilaku yang dipelajari secara sengaja maupun tidak sadar selama waktu-waktu yang lalu. Hasil skor angket memperlihatkan bahwa siswa kelas XI-IPS SMA Negeri 1 Malang memiliki kebiasaan belajar yang sangat baik berjumlah 33 orang atau $81 \%$ dari total responden, $12 \%$ siswa memiliki kebiasaan belajar yang baik, sisanya 7\% kebiasaan belajarnya masih kurang, sedangkan siswa yang kebiasaan belajarnya buruk tidak ada. Kebiasaan belajar yang sangat baik mempengaruhi prestasi belajar siswa.

Untuk menjamin hasil belajar yang baik, maka siswa harus mempunyai perhatian terhadap bahan yang dipelajarinya. Hasil skor angket menunjukkan $12 \%$ siswa memiliki perhatian yang sangat baik pada mata pelajaran akuntansi, $68 \%$ menunjukkan perhatian yang baik, sedangkan $20 \%$ sisanya menunjukkan perhatian yang kurang terhadap mata pelajaran akuntansi. Perhatian siswa terhadap mata pelajaran akuntansi membantu siswa dalam menyerap informasi yang diberikan guru maupun dari bahan pelajaran. Siswa yang kurang perhatian terhadap informasi yang diberikan berdampak siswa tersebut memiliki pemahaman yang salah terhadap bahan pelajaran akuntansi yang dipelajarinya. Perhatian yang tinggi terhadap mata pelajaran akuntansi akan membantu siswa dalam memahami materi akuntansi yang diberikan sehingga meningkatkan prestasi belajar siswa tersebut.

Siswa yang memiliki modernitas individu yang tinggi akan bersikap terbuka terhadap informasi dan selau berusaha untuk meraih kesuksesan demi masa depan siswa yang lebih bagus. Modernitas individu yang dimiliki oleh siswa kelas XI-IPS SMA Negeri 1 Malang sudah sangat bagus hal ini tercermin dalam hasil skor angket. Siswa yang memiliki modernitas individu yang tinggi sebesar $54 \%$ atau separuh dari jumlah responden. Siswa yang memiliki modernitas yang cukup baik sebesar $44 \%$ sedangkan siswa yang memiliki modernitas yang kurang hanya sebesar $2 \%$. Modernitas individu yang dimiliki siswa membantu siswa dalam mempelajari materi akuntansi. Belajar akuntansi yang tidak monoton dari buku atau dari guru akan menambah wawasan siswa tentang akuntansi karena 
akuntansi itu merupakan ilmu sosial. Salah satu ciri modernitas individu adalah orientasi terhadap waktu, artinya waktu merupakan sesuatu yang berharga. Siswa yang menghargai waktu tidak akan menunda-nunda apa yang harus dikerjakannya. Tugas-tugas akuntansi yang dikerjakan tepat waktu akan membantu siswa dalam memahami materi akuntansi dan akhirnya membantu siswa dalam meningkatkan prestasi belajarnya.

Sikap siswa yang positif terhadap mata pelajaran akuntansi merupakan awal yang baik bagi proses belajar. Sikap positif tersebut dapat terjadi karena siswa menyukai materi akuntansi dan merasa akuntansi diperlukan dalam kehidupan sehari-hari. Sikap siswa yang positif akan membantu siswa dalam meningkatkan prestasi belajar siswa. Sikap siswa kelas XI-IPS SMA Negeri 1 Malang terlihat dari hasil skor angket. Skor angket menunjukkan 15\% siswa memberikan sikap yang sangat baik terhadap mata pelajaran akuntansi, $80 \%$ atau lebih dari separuh siswa memberikan sikap yang baik terhadap akuntansi, sedangkan 5\% siswa bersikap kurang baik terhadap materi akuntansi.

Kesiapan perlu dimiliki oleh siswa karena dengan kesiapan siswa akan merasa nyaman dan tidak tertekan ketika pelajaran akuntansi akan berlangsung. Kesiapan siswa dalam menerima materi akuntansi memberikan dampak positif terhadap pemahaman akuntansi. Kesiapan menimbulkan rasa aman dan nyaman sehingga siswa tidak merasa takut. Kesiapan siswa tersebut pastinya berdampak pada pemahaman akuntansi oleh siswa sehingga juga akan meningkatkan prestasi belajar akuntansi. Kesiapan siswa kelas XI-IPS SMA Negeri 1 Malang terlihat dari hasil skor angket siswa. 5\% siswa merasa sangat siap menerima pelajaran akuntansi. $88 \%$ siswa merasa cukup siap dalam menerima pelajaran akuntansi dan 7\% siswa merasa kurang siap dalam menerima pelajaran akuntansi.

Penjelasan di atas mengenai faktor yang mempengaruhi prestasi belajar akuntansi dapat disimpulkan bahwa faktor psikologi merupakan faktor yang memengaruhi prestasi belajar akuntansi siswa XI-IPS SMA Negeri 1 Malang.

Faktor IQ merupakan faktor keempat yang mempengaruhi prestasi belajar akuntansi siswa kelas XI-IPS SMA Negeri 1 Malang. Hal ini sesuai dengan pendapat Dalyono (2007:188) bahwa faktor-faktor yang mempengaruhi inteligensi ialah keturunan, kondisi fisik, iklim emosi dan latar belakang sosial 
ekonomi. IQ besar pengaruhnya terhadap kemajuan belajar akuntansi. Siswa yang memiliki IQ tinggi lebih mudah menyerap pelajaran dibandingkan siswa yang memiliki IQ dibawahnya. Dalyono (2007:56) menyatakan bahwa seseorang yang memiliki IQ baik umumnya mudah belajar dan hasilnya pun cenderung baik. Hasil skor IQ menunjukkan bahwa 27\% siswa kelas XI-IPS SMA Negeri 1 Malang memiliki IQ yang sangat baik, 56\% memiliki IQ baik dan 17\% memiliki IQ cukup baik. Dari skor IQ menunjukkan cukup banyak siswa yang mempunyai IQ tinggi. Hal ini menjelaskan bahwa kecerdasan mempunyai peranan yang sangat besar dalam menentukan berhasil dan tidaknya siswa mempelajari akuntansi.

Berdasarkan hasil analisis faktor yang telah dilakukan pada siswa kelas XI-IPS SMA Negeri 1 Malang dapat diketahui bahwa faktor motivasi memiliki eigenvalue terbesar yaitu 3,752. Hal ini berarti motivasi merupakan faktor yang paling dominan dalam mempengaruhi prestasi belajar akuntansi siswa kelas XIIPS SMA Negeri 1 Malang. Motivasi yang muncul memberi stimulus kepada siswa untuk giat belajar dan memberikan guru pengertian perlunya memberikan motivasi kepada siswa. Seorang guru harus dapat mengaplikasikan gaya mengajarnya secara tepat dalam kegiatan pembelajarannya sehingga dapat membuat siswanya termotivasi dan menghasilkan prestasi yang optimal.

\section{SIMPULAN}

Berdasarkan analisis data yang telah dilakukan dapat disimpulkan bahwa faktor-faktor yang mempengaruhi prestasi belajar siswa pada mata pelajaran akuntansi adalah (a) faktor motivasi, (b) faktor lingkungan sosial terdiri dari relasi antaranggota keluarga dan relasi siswa dengan siswa lain, (c) faktor psikologi terdiri dari EQ, kebiasaan belajar, perhatian, modernitas individu, sikap dan kesiapan serta (d) faktor IQ. Dari beberapa faktor tersebut, faktor yang paling dominan dalam mempengaruhi prestasi belajar pada mata pelajaran akuntansi siswa kelas XI-IPS SMA Negeri 1 Malang adalah faktor motivasi. 


\section{DAFTAR RUJUKAN}

Aunurrahman. 2009. Belajar dan Pembelajaran. Bandung:Alfabeta.

Dalyono. 2007. Psikologi Pendidikan. Jakarta: Rineka Cipta.

Dimyanti dan Mudjiono. 2002. Belajar dan Pembelajaran. Jakarta: Rineka Cipta.

Djaali. 2009. Psikologi Pendidikan. Jakarta: PT Bumi Aksara.

Djamarah, Syaiful, B. 2011. Psikologi Belajar, Edisi 2. Jakarta: PT Rineka Cipta.

Goleman, Daniel (Alih bahasa oleh T. Hermaya). 2004. Emotional Intelligence, Kecerdasan Emosional Mengapa EI Lebih Penting daripada IQ. Jakarta: PT. Gramedia Pustaka Utama.

Hurlock, Elizabeth E (Alih bahasa oleh Meitasari). 2000. Perkembangan Anak. Jakarta: Erlangga.

Juwono, Wisnubroto Hendro. 2002. Pengantar Psikologi Belajar. Jakarta: Erlangga.

Khaque, Eryanti Setyoning. 2009. Pengaruh Modernitas Individu dan Latar Belakang Sosial Ekonomi Orang Tua terhadap Prestasi Belajar Siswa SMK Muhammadiyah 3 Singosari. Skripsi tidak diterbitkan. Malang: Universitas Negeri Malang.

Nasution. 2009. Berbagai Pendekatan dalam Proses Belajar dan Mengajar. Jakarta: Bumi Aksara.

Slameto. 2010. Belajar dan Faktor-Faktor Mempengaruhinya. Jakarta: PT Rineka Cipta.

Supranto, J. 2004. Analisis Multivariat Arti dan Interpretasi. Jakarta: Rineka Cipta. 